\title{
SAMOAN CUSTOM AND HUMAN RIGHTS: AN INDIGENOUS VIEW
}

\author{
Unasa L F Vaá*
}

This article focuses on human rights as seen from the perspective of Samoan custom and social life. It argues that the roots of human rights as understood by Western societies are metaphysical whereas human rights under Samoan culture stem from being born from human parents and, therefore, an heir or suli. While the genesis of rights may be different, the overall understanding of human rights, however, is argued to be the same. The article examines Samoan cultural practices in light of international human rights standards and draws parallels between them. Custom can then be seen as a source of human rights.

\section{INTRODUCTION}

One often hears the remark that Samoan children do not have human rights. ${ }^{1}$ This is despite the fact that Samoans exercise great care in bringing their children into the world and in preparing them for adult life. The problem is not that they do not have human rights, as understood in the West, but that people have different understandings of the signification of the words "human rights". In European countries, these rights are regarded as metaphysical. In Samoa, they do not exist by themselves but are embedded in the culture and are attached to social action. That is why it is often difficult to isolate them from, say, other kinds of rights found in the culture, for instance, rights to do with responsibilities and obligations.

Human rights are often described as those rights said to be held in common by all human beings by virtue of the fact that they are human. ${ }^{2}$ These rights include not just basic rights to life and liberty, but also other civil, political, economic, social and cultural rights as enumerated in the 1948

* Unasa LF Vaá, PhD (ANU) is an anthropologist, former Senior Lecturer and Head of Department of the Department of Samoan Language and Culture, Dean of the Faculty of Arts, and currently Associate Professor of Samoan Studies, Centre of Samoan Studies, National University of Samoa, Papaigalagala.

1 See for example Rev Faapaia Tariu's comments in "Translation of 'Rights' the Problem" (31 March 2008) Samoa Observer Savalalo.

2 General Human Rights Presentation (December 2003) Minnesota Advocates for Human Rights www.mnadvocates.org (accessed 12 December 2008); United States Declaration of Independence (4 July 1776); Declaration of the Rights of Man and the Citizen, French National Assembly (26 August 1789). 
United Nations Declaration of Universal Rights. Custom refers to traditional values, beliefs and practices both in a historical and developing context. This paper focuses on human rights as seen from the perspective of Samoan custom.

The modern concept of human rights, as understood by Europeans, is foreign to Samoan ways of thinking. Whereas modern European notions of human rights derive from the rationalist tradition of philosophical thought in ancient Greece, Renaissance, and Christian theological principles, such as those spelt out in Thomas Aquinas' theory of natural rights, ${ }^{3}$ and libertarian and egalitarian principles, such as those stated in the United Nations Universal Declaration of Human Rights, the equivalent ideas in Samoa emanate from custom. Samoan beliefs about human rights are based on the criterion of blood connection. This is to say, rights accrue to a human being born into this world by virtue of the fact that he or she is born from human parents and therefore an heir or suli. ${ }^{4}$

Thus, the two perspectives on human rights originate from two different perspectives, one idealistic, the other realistic, in the sense of being based on practical or pragmatic realities. The overall understanding of human rights, however, is the same, and the effect identical, as I shall explain.

\section{O LE TAGATA}

O le tagata, or the human person in Samoan society is divine in that every Samoan can trace his or her genealogy back to the High God, Tagaloalagi, the Creator of the Heavens and Earth, of the physical universe, of human beings (tagata) and their positions in society (tofiga). The same God came down to earth, in the form of his progeny (suli), through his many marriages with the beautiful daughters of the earth people. Because every Samoan can trace his or her ancestry to Tagaloalagi as a result of these marriages, every Samoan is thereby a divine suli of Tagaloalagi, a word which means "free in limitless space". ${ }^{5}$ Thus the rights that pertain to this God are also theirs. This belief means that Samoans accord dignity and respect for individual life, regardless of sex. They did not have a predilection for either male or female. Both were welcomed and treated equally from a social point of view. Thus in ancient Samoa, there was no custom of infanticide. Why? Because both males and females played valuable roles in society. This is why the birth and socialisation of children were an important aspect of Samoan custom.

The socialisation of the Samoan child began at the moment of conception through the increased tenderness and warmth in the interactions and communications between husband and wife, and between the two affinal groups of the parents. Conception means the two families will have an heir

3 See for example William P Baumgarth and Richard J Regan (eds) Thomas Aquinas On Law, Morality, and Politics (Hackett, Indianapolis, 1988).

4 Pita Le Tagaloa Ofa Se Faalepo po o se Faalani (Pacific Printers Co Ltd, Apia, 1991).

5 Ibid, 17. 
to continue the family lines and traditions. The heightened nature of the relationship will be felt by the foetus and affect its well-being and emerging intellectuality.

At the time of birth, usually at the natal home of the wife, the wife would be given a liberal share of the kind attentions of her mother, relatives and friends, and the father or husband would pray to the gods to preserve mother and baby. ${ }^{6}$ This prayer was typical: ${ }^{7}$

O Moso, be propitious; let this my daughter be preserved alive!

Be compassionate to us; save my daughter,

and we will do anything you wish

as our redemptive price.

The god whose name was called (from a list of names) at the time of birth became the child's personal god throughout its life and if male his umbilical cord would be cut on a club, so that he would be a brave warrior; if female, on the tapa board, so that she would be skilled in tapa-making. Both before and after birth, many feasts were to be held to celebrate the various milestones in a child's life. Thus, on the third day after birth, there was general rejoicing over the birth with friends bringing presents.

In accordance with custom, the husband's relatives brought oloa, such as cooked pigs, canoes, and foreign property while the wife's relatives brought fine mats, sleeping mats, native cloth, coconut oil and fans. The oloa were distributed among the wife's relatives and the toga among the husband's relatives. "Feasting, sham-fighting, night-dancing, and many other heathen customs formed one continued scene of revelry for two or three days, when the party broke up." ${ }^{8}$ But this was not all for other feasts to celebrate the birth followed. Feasts were held when the child began to crawl (totolo), when the child could stand (tu) and the fifth and greatest of all, when the child could stand and walk (savali). Turner, one of the early London Missionary Society evangelists to Samoa and who was to write extensively on his experiences, observed that Samoans were always fond of their children and would have done anything for them when ill. $^{9}$

The question naturally arises, what is the significance of this in terms of human rights? It is that children, as human beings, are regarded as people with human rights, the right to be nurtured, from womb to birth to childhood and to adulthood. Indeed they were regarded as treasures (mea sina). This right emanates from being born into a particular human family, situated in a specific

6 George Turner Samoa a Hundred Years Ago and Long Before. A Study of a Polynesian Society Before the Advent of European Influence (R McMillan, Papakura, New Zealand, 1983) 78.

7 Ibid.

8 Ibid, 82.

9 Ibid, 135. 
geographical village, geographical district and nation of people, known among their Pacific neighbours as Samoans.

Birth implies the transformation of a natural being into a social being, with all attendant rights that this entails; hence the great care exercised in the bringing of a child into the world. In Samoa, human rights begin before birth and continue throughout life as the suli attain the various milestones in their lives, first as children and members of the lalovaoa group, village children whose roles are to perform chores for their seniors; aumaga, untitled men's organisation; aualuma, unmarried daughters of the village; fono a matai, village council of chiefs; saofaiga a faletua ma tausi, organisation of the wives of the village chiefs; and au matutua, the aged. These rights are embedded in the culture and known to all.

Masiofo Filifilia Imo, wife of Samoa's current Head of State, has written succinctly on the question of human rights. In a column published in The Samoa Observer, she said that human rights of a child refer to the responsibility of parents, families and villages to look after the welfare of children: "[o]nce conception is established, the mother is subjected to a regimen which is intended to protect the life of the mother and the life of the child. The regimen is an affirmation of the rights of a child to life and good health."10

In the palagi (foreign, European) context, the question of when a foetus became a human being was an issue. But this did not arise in the Samoan context because once conception was established, the foetus was referred to as le tagata (human) and as such was entitled and deserving of every right as a human being. There are people in Samoa who would maintain that children have no human rights, but according to Rev Faapaia Tariu, this is the result of a misunderstanding by many Samoan parents. Speaking at a National Convention on the Convention on the Rights of the Child, (NCCRC), he said parents feared that such rights gave children power and authority over their parents. $^{11}$

The reality, however, was that parental authority was not reduced as a result of the NCCRC and that support for the NCCRC would lead to the success of Samoan children. The misunderstanding, in his view, was due to the translation of the word human rights to aia tatau. It would have been better if the Samoan words faamanuiaga faavae were used instead as these avoided the implications of challenging parental authority. ${ }^{12}$

10 Masiofo Filifilia Imo "Samoan Custom and the Rights of Children" (30 September 2007) The Samoa Observer Savalalo 19-20.

11 Rev Faapaia Tariu (Mapusaga o Aiga National Conference on the Convention on the Rights of the Child, Apia, Samoa, 24-28 March, 2008).

12 The English word "human right" is normally translated as "aia tatau". Critics, such as Rev Tariu, feel it is too strong, and prefer "faamanuiaga faavae" meaning original blessings, benefits, gifts, something given to the newly-born. It is a less threatening term than "aia tatau". 


\section{RIGHTS OF A SULI}

I have equated human rights with the rights of a suli or an heir of a Samoan family through both mother and father. A Samoan thus has a right to life because he or she is heir to the title, property, land and culture of his or her ancestors, together with all other rights and privileges pertaining to his or her family's social standing and responsibilities in a village. These rights are jealously guarded by members of his or her immediate and extended family and kinship group.

Discussions on the suli are not new and have been analysed extensively by other authors, both Samoan and European, ${ }^{13}$ so I will merely provide a synopsis here. A suli is an heir of a kinship group which owns one or several chiefly titles in a village. A suli is one whose rights to title, land, property, honours and so forth accrue by reason of birth, or adoption or through service.

Thus there are three kinds of suli but in turn these are ranked according to a certain order: those who are suli by virtue of birth (suli tau toto, tau aano, tau ivi) have the strongest rights to a family's title/s, land and property; then those suli who are adopted (tama fai); then finally those who acquired a family's title through service (suli tautua), often of a long-term nature and often because of the lack of natural-born heirs. ${ }^{14}$ This kinship group is described by Gilson as "a non-localized cognatic corporation headed by a matai and consisting of people born or adopted into his household and, beyond them, of their descendants outside the village of the household, which extension is limited to one or two generations." 15

Samoans resorted to adoption for several reasons: as part of ceremonial exchange, to replenish human resources usually in the event of the failure of a suli to produce heirs, or to lay a claim to higher nobility. Turner recounts a typical example in early-contact Samoa. A husband would give away his child for adoption by his sister in return for property (oloa). The adopted child was viewed as toga, and was, to the family who adopted it, a channel though which native property or toga continued to flow to that family from the parents of the child. On the other hand, the child was to its natural parents a source of obtaining property from the parties who adopted it, not only at the time of its adoption, but as long as the child lived. ${ }^{16}$

People who became suli by virtue of some form of extended service (such as physical work, providing necessities, or serving as spokespersons for a chief) often succeeded to a family's title in Samoa, in part because of the lack of active natural-born heirs or as reward for their services.

13 R P Gilson Samoa 1830 to 1900: The Politics of a Multi-Cultural Community (Oxford University Press, London, 1970).

14 Pio Mailo Palefuiono (Tofa Enterprises, Pago Pago, 1992).

15 Gilson, above n 13, 29.

16 Turner, above n 6, 83. 
Succession to a title allowed them to be called suli and entitled them to all the powers, honours and privileges of such suli, including the right, often contested, to continue to succeed to the title.

At the bottom of the scale are the affines, people who are married into a family, such as male affines (faiava) and female affines (nofo tane). These people are not entitled to the family rights of their spouses, because they are regarded as outsiders whose rights remain within their own natal groups, though they may be treated with great respect. These are called suli tupolo, or those heirs who serve with the knife, that is, responsible for domestic duties, such as cooking, preparing the oven and so on.

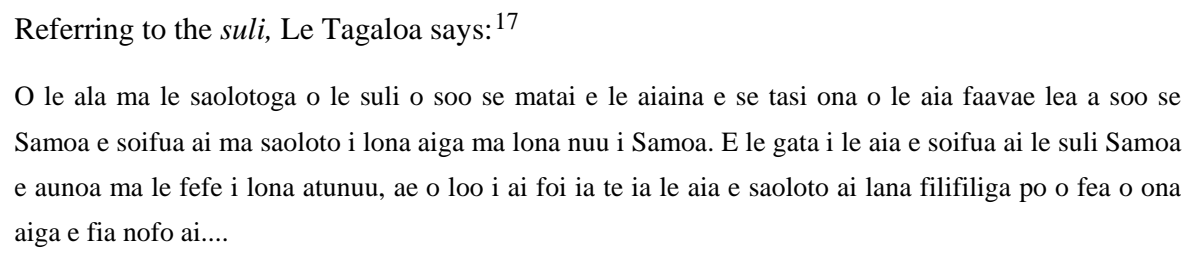

\section{THE FEAGAIGA SYSTEM}

A very important aspect of the Samoan hypothetical package of human rights (a body of rights that is often implied rather than stated) is the custom of the feagaiga, one that has been discussed extensively in literature. ${ }^{18}$ The same custom exists in Fiji as the vasu and in Tonga as the fahu, statement to an earlier common culture of the three states. In Samoa, the feagaiga means a contract between two parties, in this case, the female descendants of a title holder (or in fact of any Samoan person), and male descendants. The former are also called tulaga, tama fafine, tama sa, feagaiga, ilamutu, pae ma le auli and itu vaivai. The latter are called tama tane or itu malosi. For simplicity's sake, the most common usage in Samoa is tama tane and tama fafine. ${ }^{19}$

Not just any male descendant or female descendant is meant but a particular configuration of descent. For instance, A (male) marries B (female) and their children are C (male) and D (female). C is tama tane in this particular family, and D is tama fafine. C and D are feagaiga. When C marries,

17 Le Tagaloa, above n 4, 20. Brief translation: "The rights and freedom of the heir of any matai title are his alone. Not only is he free to live without fear from anybody, he is also free to associate with any branch of his many families."

18 W T Pritchard Polynesian Reminiscences; Or, Life in the South Pacific Islands (Chapman and Hall, London, 1866); J B Stair Old Samoa or Flotsam and Jetsam from the Pacific Ocean (Religious Tract Society, London, 1897); Gilson, above n 13; Penelope Schoeffel "Daughters of Sina: A Study of Gender, Status and Power in Western Samoa" (PhD Thesis, Australian National University, Canberra, 1979); F J H Grattan An Introduction to Samoan Custom (R McMillan, Papakura, 1985); M Meleisea The Making of Modern Samoa: Traditional Authority and Colonial Administration in the History of Western Samoa (Institute of Pacific Studies, University of the South Pacific, Suva, 1987); Mailo, above n 14.

19 Compare U L F Va'a Saili Matagi: Samoan Migrants in Australia (Institute of Pacific Studies, University of the South Pacific, Suva, 2001). 
all those descended from him are classified as tama tane vis-a-vis all those descended from $\mathrm{D}$, who are classified as tama fafine, ad infinitum. But the kinship configuration is repeated again in their children, with status being divided along gender lines. Thus assume that $\mathrm{C}$ has children $\mathrm{E}$, male, and F, female. Again, a new feagaiga relationship begins, eventually resulting in multiple layers of these relationships.

These two parties are equal, in the sense that siblings are equal, they have parents in common and have rights in common. However, while this may be true in the scheme of nature, their status and roles are prescribed for them by social expectations, norms and rules. This is unequal, though theoretically, in the end a balance is created, that is to say, harmony is created, through a system of complementarities.

According to the rules of the feagaiga, the male descendants or tama tane, succeed to a family's title, possession of family lands, and represent the family in the village council or fono. They are vested with the political authority or pule that pertains to a family. They live on the land and use the products of the land to support their sisters. The sisters are elevated in status even when married and live on the lands of their husbands. Before marriage, they often serve as ceremonial village maidens for their fathers and lead the family in important social rituals involving not just the family but also the village and district. Their job is to act as counsellors for the tama tane with the power of veto over important family decisions.

The functions of the two groups are meant to be complementary and to result in peace and harmony in a family. When either side does not play its part, trouble usually results, and it is not uncommon for litigation to arise as a result at the Land and Titles Court. This usually results from the breakdown of a feagaiga relationship or in a bid for political power by a tama fafine.

\section{CORE VALUES AND BELIEFS}

Another important source of the notion of human rights in the Samoan experience is the core values and beliefs which guide social action. It is possible to speak of an infinity of core values but I shall discuss several of the most important of these, namely, obedience, respect, love and service or in Samoa, usitai, faaaloalo, alofa, tautua, in that order. ${ }^{20}$

Usitai, obedience, is of utmost importance in the parent-child, chief-taulealea, senior-junior and other kinds of close-knit relationships. In Samoan society, it is a maxim that some give orders, for example, parents to their children, chiefs to their serving men, and others obey, for example, children to their parents, serving men to their matai, younger to the elder. The justification is that this practice is sanctioned by society for the good of its members.

Faaaloalo, respect, is a core value and is demanded of all Samoans particularly of children towards their parents, of brothers towards their sisters, of serving members towards their chiefs, of

20 Compare Mailo, above n 14. 
the young towards the old, of the au lotu, congregations, towards their pastors, of students towards their teachers, and so on. Respect is shown not merely in the manner of talking, but also in the body language of a person.

Alofa, love, is another core value which is also shared with other Polynesian societies (such as Hawaii, where it is called aloha) and this is expressed in many forms, first towards other family members, then towards members of one's village, district and nation, and finally towards all other peoples. It is universal in scope. It springs from the heart of a Samoan, from love for other humans.

Tautua, service, is typically Samoan, because it means providing service to others, family, religion, society, without hope of reward. It is voluntary service which does not seek payment but nevertheless almost invariably ends well for the provider because succession to a title is the usual reward. The culture hero known as Pili, from the seventh century, is known as the Father of Tautua in Samoa. The many stories about him reflect this spirit of selfless service. ${ }^{21}$

Among the core beliefs of the Samoans is the belief in a Superior Being, whom they used to call Tagaloalagi. While the name has since changed, Samoans have still retained many of their old beliefs associated with this Being, such as the existence of natural justice and a reward in the afterlife.

These core values and beliefs are not simply metaphysical phenomena; they also serve as springboards for social action. These in turn give rise to a corpus of human rights that may be subsumed under the rubric of tradition. These sets of rights normally begin as the expectations in specific social relationships (such as nephew and maternal uncle) but may be expanded to include others, including non-kin relationships.

That being so, the question arises: how are these rights expressed on the basis of these values and beliefs? I will be brief here. Take obedience (usitai). Superiors and employers have the right to expect obedience of those under them for the welfare of all. For example, in the course of a difficult voyage at sea, the safety of all depends on the correct actions of the captain or tautai. All passengers must obey him. An unruly passenger who does not obey may endanger the lives of all. The tautai has the right to be obeyed, the passengers to a safe journey.

Alofa is demonstrated when parents care for their young children or their children care for their old parents; in this case, children expect their parents to care for them while young, and parents expect their children to care for them when grown old. Siblings also expect help from each other, in the natural course of events, rather than from strangers. These expectations may also be expressed in terms of rights.

21 See Augustin Kramer The Samoa Islands: An Outline of a Monograph with Particular Consideration of German Samoa (Polynesian Press, Auckland, 1994) and Brother Herman Tala o le Vavau (Association of Marist Brothers' Old Boys, Pago Pago, 1955). 
Respectful behaviour (faaaloalo) is also expected of everybody. When A shows respect to B, however, that is expressed, A can properly expect B to do the same. Like begets like, and presumably unlike begets unlike. As we sow, so shall we reap, is another saying. Respect as an expectation is also a right. When it is not given the relationship becomes one of negative reciprocity.

Service (tautua) in Samoa means serving a chief through work, time and money. The service raises the status of the chief in the eyes of the community because of his ability to meet his chiefly obligations. The servant remains in the background, but he or she is usually rewarded by other means, most importantly, through succession to the family title. Again there are expectations in such relationships and these give rise to rights, such as the right to be compensated for service.

Belief in a supernatural being can lead to a belief in the right to worship in one's own way, and this has already happened in Samoa since the arrival of Evangelical Christianity in Samoa in the 1830s. The Wesleyans followed in 1835, the Catholics in 1845 and the Mormons in the 1890s. Most Samoans believe in a supernatural being but they also believe they have the right to worship their God in their own way. Indeed this was the practice in pre-Christian Samoa when there were gods galore and gods could be substituted if they were found to be ineffective.

\section{CUSTOM AND HUMAN RIGHTS}

The concepts of suli and feagaiga, are representative of Samoan notions of human rights for these spell out the rights of a suli (including the right to live and survive so as to serve the kin group and community) and those of tama tane and tama fafine. Suli rights may be regarded as universal, they apply to all Samoans, while feagaiga rights may be regarded as special rights which function to maintain a balanced relationship between the genders. These sets of rights suggest that Samoans were aware of universal human rights and women's rights, long before they were popular in the West. $^{22}$

While "universal" means the universality of the Samoan world, which may be taken to include Samoa's neighbours such as Fiji, Tonga, Tokelau, Uvea and Futuna, countries with which Samoan had frequent social contact before the entry of European settlers, the term nevertheless can be expanded to apply to other dimensions. Similar is the case of gender relations posited by the feagaiga relationship which is so prevalent and strong in Samoa that it may properly be regarded as an institution. Samoans managed to solve the problems of gender inequality long before Westerners came forward with their own notions of equality, which appear rational on paper, but still bear some unresolved conflicts. For example, if husbands and wives have equal rights, it means they also have the equal right to work but what happens to the children? Who is going to look after them? Is that not the fundamental reason for their getting married in the first place? In other words, in the faaSamoa, equality without context is meaningless!

22 Compare Schoeffel, above n 18. 
Finally, core values and beliefs are other important sources of Samoan notions of human rights because Samoans believe that values and beliefs are more than just abstract concepts, they are also guides to social action, not just for Samoans but also for others. They also serve as social markers of ethnic identity. In this sense, a Samoan who does not practice obedience, love, respect and service is not a Samoan at all. Ironically, this is not far off the mark especially if we are to search for dimensions to judge Samoan personhood!

Custom, therefore, does not merely refer to values, beliefs and practices. It also refers to human rights. Indeed, custom may be equated with human rights, and human rights with custom. This is a good starting point to discuss human rights in the context of traditional societies because first, indigenous peoples tend to regard human rights in terms of custom (kastom in Melanesia) and secondly, incorporation of Western notions of human rights is best approached through means of cultural exegesis.

\section{CURRENT STATUS OF HUMAN RIGHTS IN SAMOA}

Today in Samoa, there are two sets of human rights codes in existence: one that is based on traditional notions of human rights, as expressed in the responsibilities and obligations of individuals to their kin, affinal and non-kin groups; and one that is based on Western notions of human rights, such as those based on the philosophical principles of natural justice and divine law. Western notions of human rights are expressed in various settings, such as the English Declaration of the Rights of Man 1689, United States Declaration of Independence 1776, French Declaration of the Rights of Man and of the Citizen 1789, United States Constitution and Bill of Rights 1789, Geneva Convention 1864, the Hague Conventions 1899 and 1907, the establishment of the League of Nations and International Labour Organisation in 1919 and of the United Nations in 1945. These landmarks in the development of human rights do not exhaust the list but they are some of the main ideological sources of the modern human rights movement.

Today, it is the United Nations that has taken the lead in the formulation, enactment and enforcement of human rights principles throughout the world. In reality though, enforcement of human rights principles by the UN is complicated by factional, ethnic and religious divisions. Some of its more notable achievements include the Universal Declaration of Human Rights, ${ }^{23}$ the Covenant on Civil and Political Rights ${ }^{24}$ (and its first Optional Protocol) ${ }^{25}$ and the Covenant on

23 Universal Declaration on Human Rights (10 December 1948) UN Doc GA/Res/217A (III) [UDHR].

24 International Covenant on Civil and Political Rights (16 December 1966) 999 UNTS 171.

25 Optional Protocol to the International Covenant on Civil and Political Rights (23 March 1976) 999 UNTS 302. 
Economic, Social and Cultural Rights. ${ }^{26}$ These covenants, with the Universal Declaration of Human Rights, came to be collectively called the "International Bill of Rights".

The UN has drafted and promulgated a total of over eighty human rights instruments, including those on genocide, racial discrimination, discrimination against women, protection of refugees, torture, rights of disabled persons and rights of the child. Some of these instruments were ratified by the Samoan Government. These include the Convention on the Elimination of All Forms of Discrimination Against Women (CEDAW) ${ }^{27}$ on 25 October 1992 and the Convention on the Rights of the Child ${ }^{28}$ on 29 December 1994.

Thirty years earlier, when the constitution of the new Independent State of Western Samoa was being discussed in the constitutional conventions of the 1950s, human rights were accorded an important place and indeed, the Constitution which came into force on 1 January, 1962, does contain a provision for the protection of fundamental rights (Part II). These rights include the right to life; right to personal liberty; right to a fair trial; rights concerning criminal law; rights regarding freedom of speech, assembly, association, movement and residence; rights regarding property; freedom from inhuman treatment; freedom from forced labour; freedom of religion and freedom from discriminatory legislation. ${ }^{29}$ Thus, it can be argued that there is an entrenched place in the formal legal system for the recognition and enforcement of human rights, and moreover that these so-called fundamental rights are not incompatible with customary law, insofar as custom can be regarded as having a jural element.

My final question then is, are these two sets of human rights principles, traditional and modern, compatible or not, and if so, why? My answer to this would be yes, traditional Samoan notions of human rights and their Western counterparts are compatible, insofar as these rights do exist, though it may be more of a problem to isolate them in a traditional context, and insofar as it can be said the these rights are directed to improving the welfare of individuals, their families and communities. Human rights are not characteristically a European creation.

In pre-Christian times, Samoan notions of human rights were generated, nurtured and applied in the small cosmos that constituted the Samoan world. With the expansion of their horizons, however, so has the body of knowledge that constitutes their human rights principles. Again, expansion and development are not unique to European civilisations.

26 International Covenant on Economic, Social and Cultural Rights (16 December 1966) 999 UNTS 2.

27 Convention on the Elimination of all forms of Discrimination Against Women (18 December 1979) 1249 UNTS 13.

28 Convention on the Rights of the Child (20 November 1989) 1577 UNTS 3.

29 Constitution of the Independent State of Western Samoa 1962 Part II, Arts 3-15. 
Perhaps this is best evidenced in the evolution of political rights. Before Christianity, and indeed for a long time after, the Samoan Government was run at the village level, with a central Government being largely ceremonial. ${ }^{30}$ Since independence however, Government is based on a Westminster system, with a Head of State, Prime Minister and Cabinet, Legislative Assembly, judiciary and executive. Village Government still exists but its powers are largely those of today's local city council in the big cities of the West. ${ }^{31}$

The means of Government may have changed, but not the philosophical concept of Government domination and its tools. These have been apparent to the Austronesian ancestors of the Samoans who arrived in Samoa approximately 3,000 years ago. Their descendants, the Samoans of today, introduced the political concepts of malo (victorious side) and vaivai (losing side), following armed conflict to determine a Government. As with political rights, so with human rights, the right to life, the right to inherit the titles, lands and honours of one's family, the right to choose the manner of serving one's community, the right to marry and eke out a living, and so on. The Samoans, throughout their history, were well aware of these rights, and they exercised them.

The problem today then is not so much ignorance of what these rights are but the desire and the will to implement them. The UN still remains the ideal international organisation to implement the provisions of these human rights conventions but it cannot perform this task effectively until it can gain a responsible measure of concerted action by its members. This is the challenge for the UN for the future.

The UN's failure to accomplish its mission could mean the emergence of regional power blocs or superpowers, such as the United States, to act alone in pursuit of their own narrow, nationalistic interests, which, of course, would lead to more resentment from other power blocs and superpowers, such as Russia, or emerging superpowers such as China and India. The result could be further tension in a world that has yet to recognise that to survive all must work together.

Ironically in Samoa, Parliament, the courts and the executive have conducted a healthy relationship with customary elements of Samoan society. While so-called customary law is recognised and acknowledged by the Government primarily through the provisions of the Constitution and the more recent Village Fono Act 1990, the fact is that common law, statute law and the Constitution are the dominant means of legal administration in Samoa. This means that formal state law can and often does overrule customary law, defined as the law made by the chiefs in the village, or in compliance with custom, this being understood in a general sense.

30 Compare E Huffer and A So'o Governance in Samoa Pulega I Samoa (Asia Pacific Press, Australian National University and Institute of Pacific Studies, University of the South Pacific, 2000).

31 Ibid. 
However, having said that, it is appropriate to state here that the Samoan judicial system does not necessarily conform exactly to a legal positivist or multicultural model. While it does not treat Samoan custom on par with the formal laws of the country, as expressed through the Constitution, common law, statutes and regulations, the Samoan judicial system nevertheless takes into account the influence of cultural factors in reaching its decisions. Thus the performance of an ifoga (public apology ritual) may be considered a factor for reducing a prison sentence and this is often done.

The Samoan judicial system also does not conform to a multi-culturalist model because multiculturalism implies the simultaneous existence of two or more legal codes which do not interfere with each other, but that is not the case in Samoa. The enacted formal laws of the country always override custom, subject to certain considerations. Custom may be freely practised as long as it does not break the formal laws, as mentioned above.

In 1993, for instance, a chief of Lona village, Fagaloa, was shot and killed as a result of a decision by the village fono. The village was fed up by the insolence and disobedience of this particular chief with regard to its orders. The defence lawyer argued that the killing was justified, because the Village Fono Act gave this authority to the fono, that is to say, the law allowed this killing made in the name of custom. However, the judge ruled that Section 6 of the Village Fono Act clearly states that punishments should only be fines of food, money or animals, and an undertaking from a villager facing punishment to work in the village. Otherwise, he added, other punishments were to be reviewed by the Land and Titles Court. ${ }^{32}$ This was clearly a case of misunderstanding the law.

It might be added here, however, that the existence of this harmonious relationship between state law and custom is no guarantee that this will last forever. There may well be controversial issues, such as the Land Reform Act, that might bring this conflict, between centralised control of economic resources and localised control exercised through customary institutions, into the open. We may well see a conflict of gigantic proportions, if it is not resolved properly.

\section{CONCLUSION}

In this paper, I have argued that Samoans have long been familiar with the concept of human rights, not as Europeans view it as a product of natural justice and divine fiat, but in terms of their rights as suli, as feagaiga, and core values that they practice every day. That is to say, human rights may be translated as cultural rights, or those rights which derive from the practice of culture beginning with the creation of the Samoan cosmos by the High God, Tagaloalagi, and extending to the present. They are acquired through a body of cultural and religious knowledge accumulated over millennia and expressed through social practice. While there is a divergence in the origins of human

32 (7 November 1993) The Samoa Observer Savalalo. 
rights beliefs between Europeans and Samoans, nevertheless they are equivalent in nature (because they sustain human dignity and entitlements) and complement each other.

The state legal system and custom in Samoa operate harmoniously. While the legal system overrides custom, custom is taken into account when the courts make their decisions. This may result in lighter punishment. While custom does not substitute for the legal system and its ethical standards, it does fill the void in other areas of society, those which do not conflict with the law. For instance, village councils have the customary right to make local laws affecting curfews, the manner of dress and maintenance of the peace within (and sometimes outside) village confines. Because of the constitutional provisions about freedom of religion, no village has as yet succeeded in prohibiting their residents from worshipping in the denomination of their choice. Limitations on religious worship have always been successfully challenged in court.

There are still some challenges to the maintenance of the integrity of human rights in Samoa, especially in the area of economic and political rights. For example, the Government's decision to switch driving to the left hand side of the road has been criticised on the basis of lack of consultation with the stakeholders, hence a lack of democracy. Also, Members of the Opposition have accused the Government of trampling on their rights during parliamentary debates and in the restrictions on the formation of their political parties. There is also the controversial Land Reform Act. This raises the question: is the human rights problem in Samoa today the lack of consultation, transparency and accountability? And how are these terms to be defined and understood? Still, for the time being, the prognosis for human rights development in Samoa for the future remains good. And it will be better still when the political parties have resolved their differences. 